\title{
TEACHING CLIL IN HIGH SCHOOL: A COMPARATIVE CASE STUDY IN TRENTINO ALTO-ADIGE
}

\author{
Cristina Rebek \\ Faculty of Education, Free University of Bolzano-Bozen (Italy)
}

\begin{abstract}
The present paper represents the research design of an ongoing project conducted in two high schools in the Province of Trento, Italy, during the current school year, 2018/2019, that later on will become a PhD thesis. The aim of this research is to closely observe the implementation of a teaching method called content and language integrated learning (CLIL). The research is a qualitative one using a constructivist grounded theory (Charmaz, 2006) theoretical framework which means trying to establish an adequate theory starting from data. The interest of the project was spurred by the great results the students of the two high school have managed to achieve in such a short period of time since the Trentino Trilingue has been implemented, in November 2014.

The main research questions are: "What are the factors that influence teaching CLIL in high school? How do these factors intertwine and affect each other? What is the best combination of factors that ensure achieving the best results in teaching CLIL?"

In order to be able to answer these rather challenging research questions, data collection was initiated in October 2018 and will continue till the end of the current school year through observation, fieldnotes and interviews of the willing participants. Several CLIL modules of different subjects all taught in English, namely History, Web design, History of Art, Project Design, Geography and Science will be observed in two high schools in the Province of Trento. The lessons are being both observed and audio recorded, tasks and activities are being photographed, whenever possible, and the willing participants, i.e. the teachers and several students participating in the project, are being interviewed, on a voluntary basis. All these data obtained in the field, will be triangulated by adding the results of the tests the students normally take during a school year and the results of national tests that are compulsory in the fourth and fifth year in high school. Triangulating all these pieces of information will provide additional reliability to the findings. Further on, all collected data will be analyzed and compare using numeric and statistical methodologies and qualitative data analysis software packages.

Motto: "The more languages you speak the more human you are" (Bulgarian proverb).
\end{abstract}

Keywords: CLIL, linguistic ethnography, English, constructivist grounded theory, high school.

\section{Preamble}

"Any programme can be effective in promoting language learning. The key issues are how it has been made to work, and which factors and events have shaped success". (Kiely in Coyle, Hood \&Marsh, 2010, p. 135). There are several, successful language teaching methodologies out there, some ancient, such as the translation-memorization method, some newer, that have adjusted to the requirements of the new millennium and the globalization of our world like full immersion, bi- and multilingual teaching and content and language integrated learning (CLIL). The central aims of the present paper is the latter, that is the content and language integrated learning with a focus on the implementation of the CLIL philosophy in two high schools in Trentino, Italy.

\section{Research design}

\subsection{Introduction and literature review}

The project begins with a presentation of the topic followed by a review of the literature, followed by the theoretical framework of the paper and a definition of the concept of bilingualism using the Content and Language Integrated Learning (CLIL) term created in 1994 by David Marsh and Anne Maljers. The term CLIL is, in fact, used to define a teaching methodology that refers to teaching pupils and students 
subjects such as Maths, Science, Art, PE, Cross Curricular, Biology, Geography, etc. through a foreign language (L2). However, it is more than a teaching method, it is a philosophy. Why a philosophy? Because it talks about how a language is learned, the mental processes involved in learning a foreign language, the fact that it is more than a method and it includes lifelong, positive changes in people's brains allowing them to learn better and faster (Diamond in Gallagher, 2013). CLIL is also often referred to as an umbrella term covering both learning a content topic through a foreign language and learning that language while studying content (Gallagher, 2013).

\subsection{Content}

The content part of the project contains the ethnographic data gathered in the field where the researcher will be observing lessons for the duration of entire school year, 2018-19. Collecting data for what it may seem like such a long period of time could be unclear, however, it is necessary because collecting relevant ethnographic information takes time and cannot be rushed (Campbell and Lassiter, 2015). The process has to be allowed to take its natural course in order for the thick ethnographic descriptions to be revealed (Geertz, 1973). In fact, experts in the field of ethnography state that PhD students who choose to do ethnography have to spend at least a year "in the field", that time leads "to depth", and that ethnographers need "an extended period of on-site time in order to produce their characteristically rich and thick cultural descriptions" (Campbell and Lassiter, 2015, p. 32). By rich and thick, Campbell and Lassiter mean the same thing that ethnographers Robert Emerson, Rachel Fretz, and Linda Shaw intend when they say that

"fieldnotes inscribe the sometimes inchoate understandings and insights the fieldworker acquires by intimately immersing herself [or himself] in another world [...] by directly running up against the contingencies and constraints of the everyday life of another people. Indeed, it is exactly this deep immersion [the] 'thick description'." (in Campbell and Lassiter, 2015, p. 66).

Interviews have to be transcribed as soon as possible after being recorded and so do the final draft of the fieldnotes, in order to avoid forgetting additional elements that a participant observer has still fresh in his or her memory but that fade over time (Campbell and Lassiter, 2015). Thus, this is what it will be done after every session of observations, interviews or conversations with the participants in the project. The pictures taken during lessons will be organized and dated thoroughly. The teachers, usually, provide materials for the next lesson and encourage the researcher to ask questions about them. They also welcome feedback either positive or negative.

Data will be gathered from seven CLIL modules observed in the already mentioned high schools in Trentino. The short modules observed are ten hour modules of Graphic design, Web design, and Science. The longer ones last for approximately thirty hours and they are two History of Art modules, one of Geography and one of History of Great Britain. One of the Art History modules finished kind of abruptly on the 15th of February when the English teacher withdrew her consent to participate in the project. However, she accepted to be interviewed and she extended an invitation to another CLIL module she is conducting with another class. When the ten hour modules have finished, all seven teachers that have taught it were interviewed together with twelve students from one class and eight from another one.

Given that the data collection is an ongoing process that will end at the end of the current school year, the analysis that can be done at this time is only a preliminary one. Every day new information is being gathered, more observations and fieldnotes are being written, more willing students are being interviewed. The students that are participating in the project are aged between 14 and 19 years, that is, from the first to the fifth class, so their opinions on the CLIL modules they have been attending vary considerably, which will be reflected in the analysis.

2.2.1. CLIL contexts. Based on the on the degree of exposure, we can say that the Italian model of CLIL encountered in these two institutions is monolingual, which mean that the students are in their home country learning a subject through CLIL. There are some students that are not non-native speakers of the Italian language, but who have an optimal command of the language and their number does not exceed $20 \%$ of the entire class (Glossary of terms and concepts used in TKT: CLIL, 2009).

2.2.2. Factors. The success of the implementation of the CLIL philosophy depends on several human and organizational factors. Among the most relevant human factors we can mention the students' starting level. According to the literature and the researcher's experience as a teacher of English, the higher the level the better. However, when teaching using CLIL, a lower English level is not an impediment as long as the materials are adjusted for that level and the topic is of interest to the students. Another factor is represented by different levels inside the same class. To tackle this potential impediment, CLIL favours group work and reciprocal help. Thus, when choosing group members, teachers normally put together one or two students 
with a higher level of English and the rest with a lower level and encourage communication on the content that has been taught in English. This way, students help each other to acquire both the language and the content.

The interviews, however, have revealed a breach in this armour, because most of the students from the fifth class that were interviewed revealed that in groups the students tend to speak their mother tongue. This tendency was also noticed during class observations.

Due to the fact that the Provincial Council has implemented the Trentino trilingue law only in November 2014, some subject teachers do not have the necessary level of language required to teach in autonomy - i.e. a $\mathrm{C} 1$ level - so they are, in most cases, assisted and aided by a language teacher. From this factor derives the next ones which are related to their experience in teaching CLIL and to the balance of power between them (Blommaert, 2005).

As for the organizational factors, we can briefly mention non pedagogical and didactic factors such as the classrooms and all the other facilities that contribute to effective learning in the $21^{\text {st }}$ century, and the schedule.

\subsection{Data analysis}

The third phase of the project is data analysis which includes sorting and coding the data and ultimately answering the research questions. There is no one way to code the information obtained in an interview or during observation sessions in the classroom, therefore, the researcher has to create his or her own categories that are relevant for the topic and adapt them while going through the material. Campbell and Lassiter (2015) state that, in fact, the more you reread your fieldnotes and your conversation transcripts, the deeper your understanding of the categories you need to create is. The transcriptions are done using software packages, wherever possible.

The trust of the participants is being gained by offering to help them with creating and/or translating CLIL materials, giving feedback on the materials they have already created, helping students and teachers whenever necessary. When the students address the researcher with "prof" and ask for help and advice or when the teachers tell the researcher that she is "ormai di casa", the trust is gained. The teachers have started to open up to the researcher, confide in her, ask for her opinion at the end of each class and even trust her enough to share personal issues with her.

The context and the ambiance of the classrooms are being completed with impressions, feelings, opinions, detailed descriptions of the learning environment in both high school. Thus, the researcher can compare the two realities as accurately and as thoroughly as possible. Ethnographic work means just that, getting an "as rich a picture as possible of the environment in which the fieldwork was completed (Bloomaert and Jie, 2010, p 63). As mentioned above, pictures of the students' work, of the blackboards, books and all materials used, of the classrooms and corridors of the high schools are also taken by the researcher. All these elements will allow her "to make a careful reconstruction of the place, time and occasion on which" fieldnotes were written (idem).

2.3.1. The theoretical framework. The theory originates from Kathy Charmaz's constructivist grounded theory which is a bottom up approach, i.e., starting from data a theory is being built (Charmaz, 2006). The base for her rather bold theory were Barney Glaser and Anselm Strauss theories, who, in the late 1960s, founded and developed a new methodological proposal called Grounded Theory. This theory aims at demonstrating that qualitative investigation procedures give results that are as significant as those obtained with quantitative research methods. Thus, the Grounded Theory can be defined as a "general method of comparative analysis (...) capable of generating a theory based on data" (Glaser \& Strauss, 1967).

The methods of data collection in Grounded Theory are qualitative, such as in-depth interviews, focus groups, participant observation. However, the researcher has decided to take it to the next level by adopting a linguistic ethnography method. This way, the researcher gets to know the participants and they, in turn, learn to trust her. Thus, everybody benefits from the research. The answers to the interview questions are much honest and heartfelt and the researcher and the participants basically build a relationship from scratch that will, hopefully, go beyond the completion of the thesis. It is definitely more challenging and time consuming but a lot more rewarding.

The analysis of the data is carried out, as mentioned, together with the data collection, through three stages of coding that are becoming gradually more abstract. Through this process, data is conceptualized and categories of analysis of the phenomenon are being determined, specifically the so-called "core category" - or the main element - that allows deciphering the psycho-social process at the base of the phenomenon object of the research. Through Grounded Theory, therefore, it is possible to highlight the critical elements at the base of the investigated phenomenon, so that to obtain meaningful and useful data upon which the researcher can intervene and obtain a research-action perspective. 
The constructivist theory, too, is relevant to the project, given that Charmaz (2006) combined the Grounded Theory with the constructivist one in order to create her unique approach, that is, the Constructivist Grounded Theory, a successful mixture of the two that is more appropriate for the nowadays teaching reality. Constructivism is a very broad conceptual framework in philosophy and science and its most well-known application is the theory of learning postulated by the Russian philosopher Lev Vygotsky in the 1930s and elaborated by the American psychologist Jerome Bruner and the Swiss philosopher Jean Piaget thirty years later. It basically means that learners construct new ideas or concepts based on their current or past knowledge.

When applied to research, this theory means that the researcher has data that he or she attempts to extract a theory from. Constructivism is a qualitative research theory and is somewhat similar to the Grounded Theory where the researcher examines the data and then tries to extract a theory. The difference is that when using the constructivist approach, the researcher brings to the table his or her knowledge and not just the data he or she has obtained from the research. What Kathy Charmaz basically does is she adds to Glaser and Strauss' Grounded Theory and Vygotsky's Constructivist Theory the position of the researcher in relation to the participant. The researcher makes the actors count, he/she gives them voice and renders their experience important and meaningful.

\section{Conclusions}

In sum, we can definitely affirm that there are no bulletproof language learning methods out there. No matter how elaborated and comprehensive a teaching method is, what makes it effective is the way school systems by its representatives, i.e., the teachers, put it into practice while taking into account the factors mentioned above. Although the relationship between these factors make the difference when it comes to its success, we can confidently affirm that the role of the educator is crucial.

\section{References}

Amit, Vered (2000): Constructing the field. Ethnographic fieldwork in the contemporary world/edited by Vered Amit. London: Routledge (European Association of Social Anthropologists).

Asher, J. (2000). Learning Another Language Through Actions. Sky Oaks, CA: Sky Oaks Productions. Sixth Edition.

Behar, Ruth (2012): The vulnerable observer. Anthropology that breaks your heart. 12. print. Boston: Beacon Press.

Blackledge, Adrian; Creese, Angela (2010): Multilingualism: A critical perspective. London: Continuum (Advances in sociolinguistics).

Blackledge, Adrian; Creese, Angela (2014): Heteroglossia as practice and pedagogy. Dordrecht: Springer (Educational linguistics, Volume 20). Available online at http://www.springer.com/gb/ BLDSS.

Blommaert, Jan (2005): Discourse. A critical introduction, Cambridge: Cambridge University Press.

Blommaert, Jan; Jie, Dong (2010): Ethnographic fieldwork. A beginner's guide. Bristol: Multilingual Matters.

Bloom, Benjamin Samuel (1956): Taxonomy of educational objectives. The classification of educational goals. New York, London: McKay; Longman.

Bryant, Antony; Charmaz, Kathy (2010): The SAGE handbook of grounded theory. Los Angeles: SAGE.

Campbell, Elisabeth; Lassiter, Luck Eric (2015): Doing Ethnography today: Theories, Methods, Exercises. USA: Wiley Blackwell.

Charmaz, Kathy (2002): Qualitative Interviewing and Grounded Theory Analysis. In Jaber F. Gubrium, James A. Holstein (Eds.): Handbook of interview research. Thousand Oaks, Calif., London: Sage Publications, pp. 675-694.

Charmaz, Kathy (2014): Constructing grounded theory. 2nd edition. Los Angeles: SAGE (Introducing qualitative methods).

Contardi, Anna; Piochi, Brunetto (2002): Le difficoltà nell'apprendimento della matematica. Metodologia e pratica di insegnamento. Trento: Erickson (Guide per l'educazione, 56).

Copland, Fiona; Creese, Angela; Rock, Frances; Shaw, Sara (2015): Linguistic ethnography: Collecting, analyzing and presenting data. Los Angeles: SAGE.

Coyle, Do; Hood, Philip; Marsh, David (2010): CLIL. Content and language integrated learning. Cambridge: Cambridge University Press.

Creese, Angela; Blackledge, Adrian (2010): Translanguaging in the Bilingual Classroom: A Pedagogy for Learning and Teaching? In The Modern Language Journal 94 (1), pp. 103-115. DOI: $10.1111 / \mathrm{j} .1540-4781.2009 .00986 . x$. 
Cummins, Jim (1984): Bilingualism and special education. Clevedon: Multilingual Matters.

Cummins, Jim (1984): Bilingualism and special education. Issues in assessment and pedagogy. Multilingual Matters Ltd (Multilingual matters, 6).

Cummins, Jim (2000): Language, power and pedagogy. Bilingual children in the crossfire. Multilingual Matters (Bilingual education and bilingualism, 23).

Diamond, Jered, (2010). The Benefits of Multilingualism, Science 330, 332.

Delibera $\mathrm{n}^{\circ} 2055$ of 29/11/2014 proposed by ROSSI UGO

Emerson, Robert M.; Fretz, Rachel I.; Shaw, Linda L. (2011): Writing ethnographic fieldnotes. 2nd ed. Chicago, Ill., London: University of Chicago Press.

Flick, Uwe; Kvale, Steinar; Angrosino, Michael V. Doing ethnographic and observational research; Barbour, Rosaline S. Doing focus groups; Banks, Marcus. Using visual data in qualitative research;

Gallagher, Elaine: Bilingual Transformation - The Effects of Globalization on Bilingual Education. Chicago State University Education Journal, Fall 2013

Geertz, Clifford (1973): The interpretation of cultures; selected essays.

Glaser, Barney G. (1967): The discovery of grounded theory. Strategies for qualitative research. New York: Aldine de Gruyter.

Glossary of terms and concepts used in TKT: CLIL (2009): Cambridge University Press.

Gubrium, Jaber F.; Holstein, James A. (Eds.) (2002): Handbook of interview research. Thousand Oaks, Calif., London: Sage Publications.

Gumperz, John Joseph (1982): Discourse strategies. Cambridge: Cambridge University Press (Studies in interactional sociolinguistics, 1). Available online at https://doi.org/10.1017/CBO9780511611834.

Jones, Marilyn Martin; Blackledge, Adrian; Creese, Angela (2012): The Routledge handbook of multilingualism. London, New York: Routledge (Routledge handbooks in applied linguistics).

Kirby, Sandra L.; Greaves, Lorraine; Reid, Colleen (2006): Experience research social change: Methods beyond the mainstream. 2nd ed. Peterborough Ont. and Orchard Park NY: Broadview Press.

Marcus, George E. (1998): Ethnography through thick and thin. Princeton, N.J., Chichester: Princeton University Press.

Marzano, Robert J.; Kendall, John S. (2007): The new taxonomy of educational objectives. 2nd ed. Thousand Oaks, CA: Corwin Press.

Marzano, Robert J.; Kendall, John S. (2008): Designing \& assessing educational objectives [electronic resource]: Applying the new taxonomy / Robert J. Marzano, John S. Kendall. Thousand Oaks: Corwin Press.

Mills, Jane; Bonner, Ann; Francis, Karen (2006): The Development of Constructivist Grounded Theory. In International Journal of Qualitative Methods 5 (1). DOI: 10.1177/160940690600500103.

Morse, Janice M. (2009): Developing grounded theory. The second generation / Janice M. Morse ...[et al.]. Walnut Creek, Calif.: Left Coast; [Oxford: Berg (Developing qualitative inquiry).

Peters, Michael A. (Ed.) (2015-): Encyclopedia of Educational Philosophy and Theory. Singapore: Springer Science and Business Media.

T. Piske and M. Young-Scholten (Eds.) Input Matters in SLA. Bristol: Multilingual Matters. pp. 81-94.

Schensul, Jean J. (1999): Enhanced ethnographic methods: Audiovisual techniques, focused group interviews, and elicitation techniques. Lanham, MD: Altamira Press.

Schreier, Margrit (2012): Qualitative content analysis in practice. London: SAGE.

Shaw, Sara; Copland, Fiona; Snell, Julia (2015): An Introduction to Linguistic Ethnography: Interdisciplinary Explorations. In Julia Snell, Sara Shaw, Fiona Copland (Eds.): Linguistic Ethnography, vol. 11. London: Palgrave Macmillan UK, pp. 1-13.

Spradley, James P. (1979): The ethnographic interview. New York, London: Holt.

SWD 2012_372-Language competences for employability, mobility and growth, Strasbourg.

Taber, Keith S. (2015-): Methodological Issues in Science Education Research. In Michael A. Peters (Ed.): Encyclopedia of Educational Philosophy and Theory. Singapore: Springer Science and Business Media, pp. 1-6.

Tedick, Diane J. (2005): Second language teacher education: International perspectives / edited by Diane J. Tedick. Mahwah, N.J. and London: Lawrence Erlbaum Associates.

Vygotsky, L. S. (1978). Mind in Society: The development of higher psychological processes. Cambridge, MA: Harvard University Press. 